\title{
Nutrient composition of cowpeas infested with Callosobruchus Maculatus L. in Zaria.
}

\author{
Mbah, C.E.* and Silas, B \\ Department of Biological Sciences, \\ Ahmadu Bello University, \\ Zaria, Nigeria. \\ *Address for correspondence: E-mail: drcemba@yahoo.com
}

\begin{abstract}
Cowpeas infested with Callosobruchus maculatus, in Zaria were analysed using standard biochemical methods. The analysis was to determine the effect of Callosobruchus maculatus on cowpeas at various stages of infestation. Four varieties "Kannanado", Local brown, "Dan Borno" and IAR-48 were used. Results show significant decrease in moisture with increase in infestation in all the varieties except for 'Kannanado', this was also the case in carbohydrate content for all the varieties used ( $\mathrm{p}<0.05$ ). The carbohydrate content (lowest was 10.3\%) for uninfested "Dan Borno" while the infested IAR-48 had the highest (12.4\%) Slightly infested seed had the highest moisture content $(12.0 \%)$ while uninfested

in protein content with severity of infestation was observed in the varieties used, though I.A.R. 48 deviated from this pattern $(\mathrm{p}<0.05)$. Uninfested "Dan Borno" had the lowest protein content (1.4\%) and IAR-48 the highest $(1.7 \%)$. Lowest lipid content was found in slightly infested seeds $(15.6 \%)$ and the highest $(22.6 \%)$ for the severely infested. A significant increase in lipid and ash contents of the cowpeas with increase in severity of infestation was observed in all the varieties $(p<0.05)$. The damage caused by $C$. maculatus to all varieties of cowpea analysed did not significantly affect their nutrient composition though they attract less market value than uninfested varieties.
\end{abstract} cowpeas had lowest moisture (5.8\%). A trend of increase

\section{INTRODUCTION}

$\mathrm{I}^{\mathrm{n}}$ Nigeria, cowpea is consumed in the form of bean Ipudding, bean cake, baked beans, fried beans, bean soup amongst others. Callosobruchus maculatus (Coleoptera: Bruchidae) is a major insect pest of cowpea. It is a cosmopolitan pest of cowpea in the tropics and subtropics of the world and an important field and store pest of pulse crops in Africa and Asia (Hill, 1983; Ogunwolu and Odunlami, 1996). It is commonly referred to as cowpea weevil. The adult weevil measures about 2.5 to 3.5 millimetres ( $\mathrm{mm}$ ) in length. It is a short chunky beetle of general brownish colour flecked with white, brown and grayish patches, also with white tufts of minute hairs. It constitutes a serious threat to the cowpea-
Key words: Nutrient composition, cowpeas, infestation, Callosobruchus maculatus. 
$39.9 \%$ fibre, $3.6 \%$ ash, $1.3 \%$ fat (Purseglove, 1977). This is comparable to the calculated digestible nutrients obtained by Oyenuga (1959), crude protein $24.7 \%$, true protein $22.8 \%$, ether extract (oil) $2.5 \%$, crude fibre $1.8 \%$, nitrogen free extracts $67.3 \%$.

The main advantage of cowpea over many other crops apart from being the most practical source of storable and transportable protein is due to the fact that it is a cheap source of protein. However, it is susceptible to many diseases and pest attack right from its growth stage up to storage (Singh et al., 1997) and final consumption (Purseglove, 1977). In Nigeria alone, losses caused by this insect pest in storage is estimated at 3.6 billion naira each year (Buckmire, 1978; Pierrard, 1986). According to Baier and Webster (1992) the criteria that served as guideline in the search for a successful and appropriate on-farm cowpea storage treatment include: farmers' opinion of the treatment which reflects potential for adoption; easy and safe application at the small farm level; availability of treatment materials, non-toxicity of treatment to the applicator, consumer preference, and the environment; treatment that effectively controls bruchids; retention of seed germination potential; maintained seed flavour and appearance; and economical or cost-effective treatment (Rachie and Singh, 1985). The developmental stage and age of insect pests treated is known to influence the susceptibility of insects to insecticides (Buraimoh, et al; 2001).

In Nigeria and many developing third world countries, there is a decline in the use of chemical insecticides due to the withdrawal of subsidies on these pesticides by the government (Lale, 1995; Lale and Yusuf, 2001). Work on the toxic effect of oils of Dennettia tripetala, Azadirachta indica, rice bran and palmkernel oil on Callosobruchus maculatus has been carried out by several researchers such as Shaaya et al. (1997) with a view to providing readily available natural materials that control the degree of infestation. This research is designed to investigate the effect of cowpea weevil on nutrient composition of cowpeas, to estimate by chemical analysis the nutrient value of uninfested and infested cowpea. To account for the qualitative loss in cowpea during storage with a view to highlighting the deleterious effects of weevil infestation on stored cowpeas.

\section{MATERIALS AND METHODS}

Different varieties of cowpea were identified at the I.A.R. Zaria. Samples of four varieties of uninfested and infested cowpeas were obtained from Kwangila, Sabo and Samaru markets randomly. Collected samples were "Kannanado", Local brown, "Dan Borno" and I.A.R. 48 (Sampea-7), sorted according to the level of infestation into groups of uninfested with no emergence hole, slightly infested with 1-2, moderately infested with 3-4, and severely infested with 5 and above number of emergence holes per seed.

Each sorted group was placed in a transparent glass jar and covered with nets (mesh size $1 \mathrm{~cm}$ by $1 \mathrm{~cm}$ ) in order to enhance continuity of infestation. The uninfested group served as the control and was tightly sealed with a metallic lid. Each sample was well labeled with the variety, source and date of collection, and the level of infestation. All the seeds of a given grouped sample were checked for eggs with the aid of a dissecting microscope VT-II at low power (magnification x10). Seeds were dissected and the larvae, pupae and adults of Callosobruchus maculatus removed with the aid of a pair of fine forceps. Seeds were then blended for each given grouped sample and analysed for moisture, ash, lipid, protein and carbohydrate, using standard biochemical analytical methods (Oyeleke, 1984) to determine the effect of infestation by Callosobruchus maculatus on cowpea's nutrient composition. The prepared blended samples were tested for moisture using the "dry weight basis" of the sample. 
Moisture $(\%)=\frac{\text { loss in weight during drying } \times 100}{\text { weight of the sample }}=\underline{\mathrm{W}_{2}} \frac{-\mathrm{W}_{3}}{\mathrm{~W}_{2}} \times 100$

Ash by ashing out in a muffle furnace.

$\operatorname{Ash}(\%)=\frac{\text { weight of ash }}{\text { weight of sample }} \times 100=\frac{\mathrm{W}_{3}}{\mathrm{~W}_{2}-\mathrm{W}_{1}} \times 100$

Lipid through Sohlex extraction (methanol 95\%).

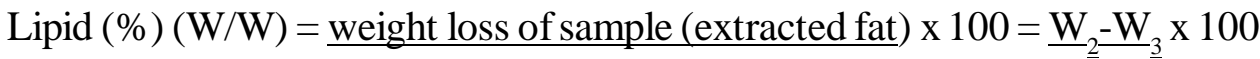

$$
\text { weight of sample } \quad \mathrm{W}_{2}-\mathrm{W}_{1}^{2}
$$

Protein through the Kjeldahl method on $0.1 \mathrm{~g}$ of dry sample

Protein $(\%)=$ nitrogen $(\%) \times$ conversion factor $(6.25)$

Nitrogen $(\%)=\frac{(\mathrm{A}-\mathrm{B}) \times 0.002 \times 14.007}{\mathrm{~W}} 100$

$\mathrm{W}$

Where, $\mathrm{A}=$ Titre value of test sample, $\mathrm{B}=$ Titre value of blank, $\mathrm{W}=$ Weight of sample in milligrams, 0.002 $=$ Normality of $\mathrm{HCl}$ used as titrant, and $14.007=$ Atomic mass of nitrogen in ammonia.

Total available carbohydrate (as \% glucose) through the Clegg-Anthrone method (Oyeleke. 1984) using $0.4 \mathrm{~g}$ of the dry sample.

Glucose $(\%)=\frac{2.5 \times \mathrm{G}(\text { concentration } \times 10)}{\text { weight of sample }}=\frac{2.5 \times \mathrm{CX} 10}{\mathrm{~W}}$

Each analysis was done in duplicates, with uninfested seeds' group serving as the control.

Results were subjected to analysis of variance (ANOVA) according to Parker (1980) to determine the level of significance of any differences between groups at different levels of infestation.

\section{RESULTS AND DISCUSSION}

The main results for nutrient content of the different varieties at different levels of infestation are shown in Figs. 1-5. The moisture content in "Kannanado" was observed to increase with increase in the level of infestation. The lowest was found in the slightly infested seeds (7.0\%) and the highest was $7.5 \%$ for the severely infested (Fig. 1). But in Local brown the result showed that the moisture content decreased with severity of infestation so that the slightly infested seeds had the highest moisture content $(12.0 \%)$ and the least moisture content was seen in the severely infested Local brown (7.1\%). "Dan Borno" also showed a similar pattern of decrease with severity of infestation, and likewise I.A.R. 48 which followed the same trend. When the above results were compared with the uninfested cowpeas it was observed that uninfested "kannanado" had the lowest moisture content (5.8\%) and uninfested Local brown the highest (13.0\%).

Analysis of the data from the four cowpea varieties at different levels of infestation show no significant difference in the moisture content of uninfested and slightly infested seeds ( $p>0.05)$ while, Local brown and "Dan Borno", Local brown and I.A.R. 48 show significant difference with respect 
to moisture content $(\mathrm{p}<0.05)$, Table 1 . The level of infestation, the variety of cowpea and the interaction between them were found to be highly significant with respect to the moisture content $(\mathrm{p}<0.01)$, Table 1 .

The protein content in "Kannanado" was observed to increase with severity of infestation. The lowest was found in the slightly infested seeds (1.8\%) and the highest was 3.2\% for the severely infested (Fig. 2). Local brown also showed a similar pattern of increase with severity of infestation, and likewise "Dan Borno" which followed the same trend. But in I.A.R. 48 the result showed that the protein content decreased with severity of infestation so that the slightly infested seeds had the highest protein content $(10.4 \%)$ and the severely infested seeds the least $(2.3 \%)$. When the above results were compared with the uninfested seeds it was observed that uninfested "Dan Borno" had the lowest protein content (1.4\%) and the uninfested I.A.R. 48 the highest (1.7\%). Analysis of the data from the four cowpea varieties at different levels of infestation show significant difference in the protein content of uninfested seeds and seeds infested at all levels of infestation ( $\mathrm{p}<0.05)$, Table 1. "Kannanado" and "Dan Borno" show significant difference with respect to protein content $(\mathrm{p}<0.05)$, Table 1 . The level of infestation, the variety of cowpea and the interaction between them were found to be highly significant with respect to protein content $(\mathrm{p}<0.05)$, Table 1 .

In "Kannanado", the carbohydrate content was observed to decrease with severity of infestation. The highest was found in the slightly infested seeds $(10.5 \%)$ and the lowest was $7.1 \%$ for the severely infested seeds (Fig. 3). Local brown also showed a similar pattern of decrease with severity of infestation, and likewise I.A.R. 48 which followed the same trend. But in "Dan Borno" the result showed that though carbohydrate decreased with severity of infestation, there was an increase in carbohydrate content of the severely infested seeds $(8.8 \%)$ when compared with the moderately infested seeds $(8.1 \%)$. When these observations were compared with the uninfested seeds it was shown that uninfested "Dan Borno" had the lowest carbohydrate content $(10.3 \%)$ and uninfested I.A.R. 48 the highest (12.4\%). Analysis of the data from the four cowpea varieties at different levels of infestation show no significant difference in carbohydrate content of uninfested seeds and seeds at any level of infestation. Also, there is no significant difference in carbohydrate content of all the varieties ( $p>0.05$ ), Table 1. Thus, the level of infestation, the variety of cowpea and the interaction between them were seen to have no significant effect with respect to carbohydrate content ( $\mathrm{p}>0.05$ ), Table 1 .

Lipid content in "Kannanado" was observed to increase with increase in the level of infestation. The lowest was found in the slightly infested seeds $(15.6 \%)$ and the highest was $22.6 \%$ for the severely infested (Fig. 4). The Local brown also showed a similar pattern of increase with severity of infestation and likewise "Dan Borno" and IAR. 48, which followed the same trend. When the above results were compared with the uninfested cowpeas it was observed that uninfested "Kannanado" had the lowest lipid content (11.0\%) and uninfested Local brown, the highest $(16.2 \%)$. Analysis of the data from the four cowpea varieties at varying levels of infestation show no significant difference in lipid content of uninfested and slightly infested seeds $(\mathrm{p}<0.05)$, Table 1. However, there is significant difference in lipid content of Local brown and "Kannanado", and also that of Local brown and "Dan Borno" ( $\mathrm{p}<0.05)$, Table 1.

The ash content in "Kannanado" was observed to increase with severity of infestation. The lowest was found in the slightly infested seeds (3.6\%) and the highest was $6.6 \%$ for the severely infested (Fig. $5)$. The Local brown also showed a similar pattern of increase with severity of infestation, and likewise "Dan Borno" and I.A.R. 48 which followed the same trend (Fig. 5). When the above results were compared with the uninfested cowpeas it was observed that uninfested "Dan Borno" had the highest ash content (3.6\%) compared with the other 
uninfested varieties with ash content of about 3.0\%. Analysis of the data from the four cowpea varieties at different levels of infestation show that there is a significant difference in the ash content of uninfested seeds and seeds infested at any level of infestation $(\mathrm{p}<0.05)$, Table 1. It was also shown that there is significant difference in ash content of "Dan Borno" and the other varieties $(\mathrm{p}<0.05)$, Table 1 . The level of infestation and the variety of cowpea were seen to be highly significant with respect to ash content $(\mathrm{p}<0.01)$. Conversely, the interaction between the level of infestation and the variety of cowpeas show no significance with respect to ash content ( $p>0.05)$, Table 1.

Between April and August, 2002 covering a segment of dry and wet seasons, four varieties of cowpeas namely "Kannanado", Localbrown, "Dan Borno" and I.A.R. 48 (Sampe-7), were randomly collected from three sources; Samaru warehouse, Kwangila and Sabo markets and analysed for proximate nutrient composition of the seeds.

Generally moisture content of cowpea seeds was observed to decrease with severity of infestation. This was similar to results obtained by Kwatamdia(1983). However, in the present study moisture was observed to increase with severity of infestation in "Kannanado". The decrease in moisture content with severity of infestation may be attributed to the metabolic and or respiratory activities of Callosobruchus maculatus, this is probably because the pest utilizes the moisture in the infested seeds for growth and other activities. This apparent increase in moisture content of "Kannanado" with increase in severity of infestation could be attributed to the fact that the samples were procured from different sources under variable storage conditions. Storage factors, variety, geographical location and time of the year affect moisture content (Collier, 1964). It is evident however, that taken together, the level of moisture in uninfested seeds when compared to the infested varieties is not significant ( $\mathrm{p}>0.05)$.
The protein content was observed to increase with severity of infestation. This is similar to the result obtained by Sowunmi (1977), who reported an increase in crude protein content in moderately infested cowpeas of $26.52 \mathrm{~g} / 100 \mathrm{~g}$ compared with $23.68 \mathrm{~g} / 100 \mathrm{~g}$ of uninfested cowpeas. And highly infested cowpeas gave a value of $27.32 \mathrm{~g} / 100 \mathrm{~g}$ compared to the values for uninfested cowpeas $(23.68 \mathrm{~g} / 100 \mathrm{~g})$. However, in the present study protein content was observed to decrease with severity of infestation in I.A.R. 48. The increase in protein content with severity of infestation may be due to the eggs, egg cases, excretory products left behind on removal of larval, pupal and adult stages of Callosobruchus maculatus before analysis. The apparent decrease in protein content of I.A.R. 48 with increase in severity of infestation is probably due to the fact that it was procured from different sources and must have grown under different environmental conditions.

Carbohydrate content was observed to decrease with severity of infestation. This is similar to the result obtained by Kwatamdia, (1983). This decrease in carbohydrate with severity of infestation may be as a result of the feeding activities of the larvae buried deep in the seeds. Generally the lipid content of the cowpea analysed was observed to increase with severity of infestation. The increase may be attributed to presence of eggs, egg cases and excretory products of the pest. It was observed that lipid content tend to increase as protein content increases. With respect to ash, an increase was observed with increase in infestation. This may be attributed to the feeding activities of Callosobruchus maculatus generating a lot of residue, which amounts to ash. In the absence of ethanol, 95\% methanol was used as solvent for sohlex extraction, this may have reduced the efficiency of lipid extraction. Irregular supply of electric power influenced the duration of drying using electric oven, and the duration of aching out in the muffle furnace. More time was required to run more replicates to get more accurate result for each cowpea variety. 


\section{CONCLUSION}

Generally, lipid, ash and protein contents of the cowpea were observed to increase with severity of infestation, whereas moisture and carbohydrate contents decreased with severity of infestation. The apparent increase in the protein and lipid content of the cowpea varieties analyzed does not in any way indicate that the infested cowpeas contain more protein and lipid than uninfested ones because the difference is not significant, rather it shows the infested varieties analysed, have not suffered much damage in comparison with the uninfested ones, so that all the varieties of cowpea used in this study were still marketable for human and animal consumption. But, where the damage has reached an advanced stage to the extent that infested cowpeas have about 8 or more emergence holes, it is usually unmarketable and unusable due to the residue and odour resulting from the feeding and excreta (frass) of the pest.

It is recommended that more work be done on essential amino acids in cowpea seeds at different levels of infestation, with the aim of recommending the level beyond which it could no longer be used for domestic and livestock consumption.

\section{REFERENCES}

Amirshahi, M.C. (1970). Tropical crops Dicotyledon. Longman, p 32-326.

APMEU (1990). Agricultural Products Monitoring and Evaluation Unity of Federal Ministry of Agriculture. In: Bioscience Research Communications 11:3

Baier, A.H. and Webster, B.D. (1992). Control of Acanthoscelides obtectus Say (Coleoptera: Bruchidae) in Phaseolus vulgaris seed stored on small farms - II. Germination and Cooking Time. Journal of Stored Products Research 28(4):295-299.
Buckmire, K.U. (1978). Pests of Grain Legumes and their control in the commonwealth Carribean. NY Academic Press, p.179-184.

Buraimoh, G.L., Ofuya, T.I. and Aladesanwa, R.D. (2001). Observations on activity of some synthetic insecticide dusts against Callosobruchus maculatus (F) (Coleoptera:Bruchidae). Bioscience Research Communications. (In Press).Collier, E. (1964). Laboratory Techniques in Botany Butterworths London, p. 353-354.

Hill, D.S. (1983). Agricultural insect pests of tropics and their control. 2nd edition. Cambridge University Press. London, New York, p.455.

Kwatamdia, P.M. (1983). Effect of cowpea beetle on cowpea nutrient value. Unpublished B.Sc. Zoo1. Project A.B.U. Zaria, p. 41.

Lale, N.E.S. (1995). An overview of the use of plant products in the management of stored products' Coleoptera in the tropics. Post harvest News and Information 6(6):69N-75N.

Lale, N.E.S. and Yusuf, B.A. (2001). Potential of varietal resistance and Piper guieense seed oil to control infestation of stored millet seeds and products by Tribolium casteneum (Herbst). Journal of Stored Products Research 37:63-75.

Ogunwolu, E.O. and Odunlami, A.T. (1996). Suppression of seed bruchid Callosobruchus maculatus (F) development and damage on cowpea (Vigna unguiculata (L) Walp) with Zanthoxyllum zanthoxyloides (Lam). Waterm (Rutaceae) root bark powder when compared to neem seed powder and pirimiphos-methyl. Crop Protection 115(7): 603-607.

Osuji, F. (1985). Outlines of Stored Products. Entomology for the Tropics. Fourth Dimension Publishers, Nigeria. p.29-31. 
Oyeleke, O.A. (1984). Outline for Food Analysis. Dept. of Biochem, A.B.U. Zaria, Nigeria. p. 23-41.

Oyenuga, V.A. (1959). Nigeria's Feeding Stuff. Their composition and Nutritive Value. 2nd ed. Ibadan University Press, p.15-60.

Parker, R.E. (1980). Introductory Statistics for Biology. Studies in Biology Series. No 43, p147

Pierrard, G. (1986). Control of cowpea weevil, Callosobruchus maculatus, at the farmer level in Seneqal. Tropical Pest Management. 32:197-200. Purseglove, J.W. (1977). Tropical crops. Dicotyledaris. Longman GroupLtd (1968), p. 321322.

Rachie, K.O. and Singh, R. (1985). Cowpea Research, Production and Utilization. John Wiley and Sons Ltd. Toronto, p. 268-270.
Shaaya, E., Kostjukovski, M., Eilberg, J. and Sukprakarn, C. (1997). Plant oils as fumigants and contact insecticides for the control of storedproduct insects. Journal of Stored Products Research 33(1):7-15.

Singh,B.B.,Mohan-Raj, D.R., Dashiel, K.E. and Jackai, L.E.N. (1997). Advances in Cowpea Research-Post Harvest Storage of Cowpea in SubSaharan Africa. I.I.T.A./JIRCAPublication, I.I.T.A. Ibadan, Nigeria, p 302-312.

Sowunmi, O.U. (1977). The effect of insect infestation on cowpea (Vigna unguiculata). II. Nigeria. Stored Products Research Institute 4:44-53.

Table 1: Duncan's Multiple Range Test on nutrient composition of cowpea varieties.

\begin{tabular}{|c|c|c|c|c|c|c|c|c|}
\hline \multirow[b]{3}{*}{ Moisture } & \multicolumn{3}{|c|}{ Infestation } & \multicolumn{4}{|c|}{ variety } & \multirow[b]{2}{*}{ IAR } \\
\hline & 1 & 2 & 3 & 4 & Ka & Lo & Da & \\
\hline & $8.526_{a}$ & $8.311_{\mathrm{a}}$ & $7.377_{\mathbf{b}}$ & $5.979_{\mathrm{c}}$ & $6.884_{b}$ & $10.333_{\mathrm{a}}$ & $7.293_{b}$ & $5.720_{c}$ \\
\hline Protein & $1.571_{d}$ & $2.066_{c}$ & $2.368_{b}$ & $2.773_{\mathrm{a}}$ & $2.157_{b}$ & $2.357{ }_{\mathrm{a}}$ & $1.963_{c}$ & $2.300_{\mathrm{a}}$ \\
\hline Carbohydrate & $9.414_{\mathrm{a}}$ & $9.774_{\mathrm{a}}$ & $7.977_{\mathrm{a}}$ & $7.610_{\mathrm{a}}$ & $9.141_{\mathrm{a}}$ & $9.055_{\mathrm{a}}$ & $8.977_{\mathrm{a}}$ & $7.602_{a}$ \\
\hline Lipid & $13.774_{\mathrm{c}}$ & $16.608_{c}$ & $20.804_{b}$ & $24.703_{\mathrm{a}}$ & $16.289_{b}$ & $22.270_{a}$ & $15.956_{\mathrm{b}}$ & $21.373_{\mathrm{a}}$ \\
\hline Ash & $3.176_{d}$ & $3.723_{c}$ & $5.483_{\mathrm{b}}$ & $7.053_{\mathrm{a}}$ & $4.666_{b}$ & $4.812_{b}$ & $5.319_{\mathrm{a}}$ & $4.638_{b}$ \\
\hline
\end{tabular}

Means with different letters are significantly different $(p<0.05)$

Infestation 1- Uninfested, 2- Slightly infested, 3-Moderately infested, 4- Severely infested. Varieties 1-”Kannanado”, 2- Local brown, 3- "Dan Borno”, 4- I.A.R 48 ( Sampea -7) 


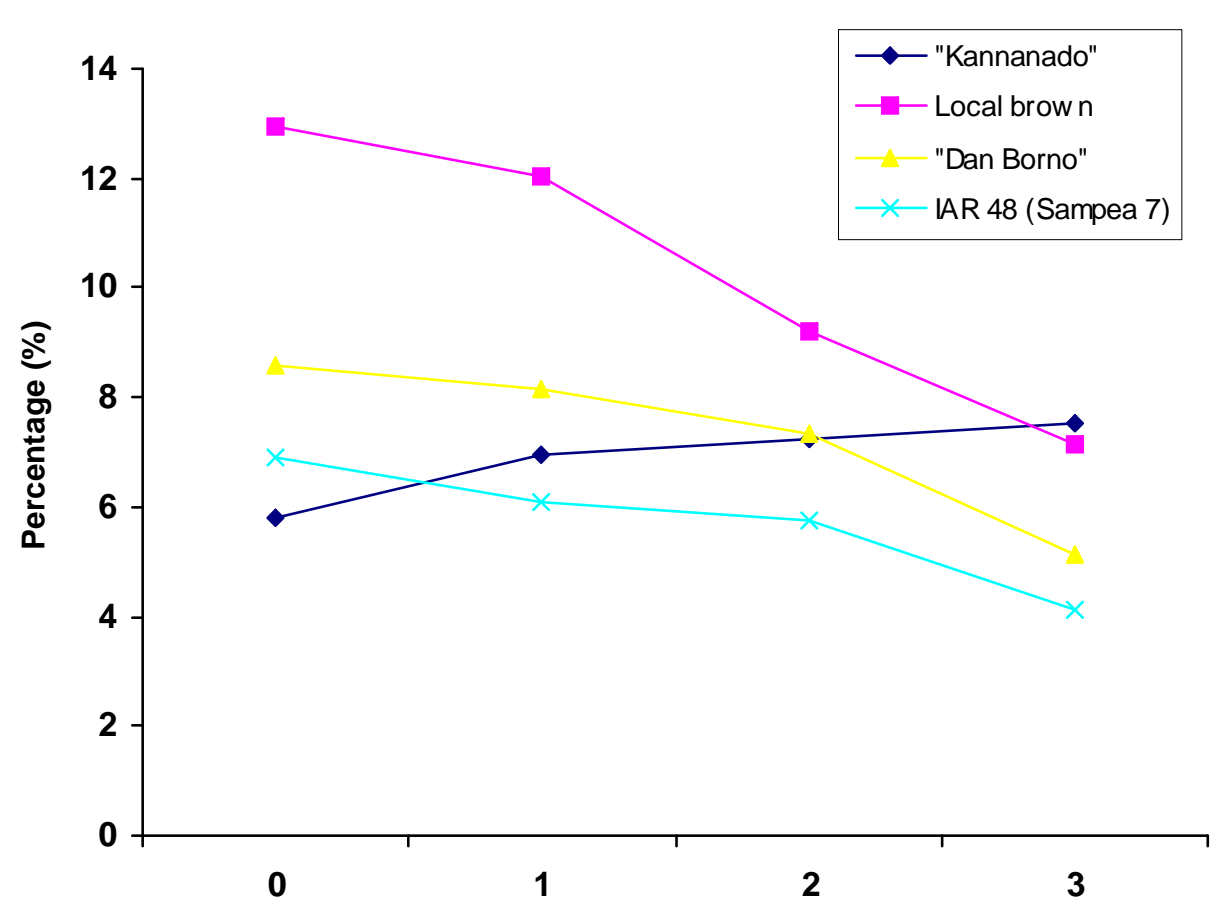

Fig.1 Variation in moisture content $(\%)$ with infestation

Levels of infestation

0- uninfested, 1 - slightly Infested, 2-moderately Infested, 3-severely infested 


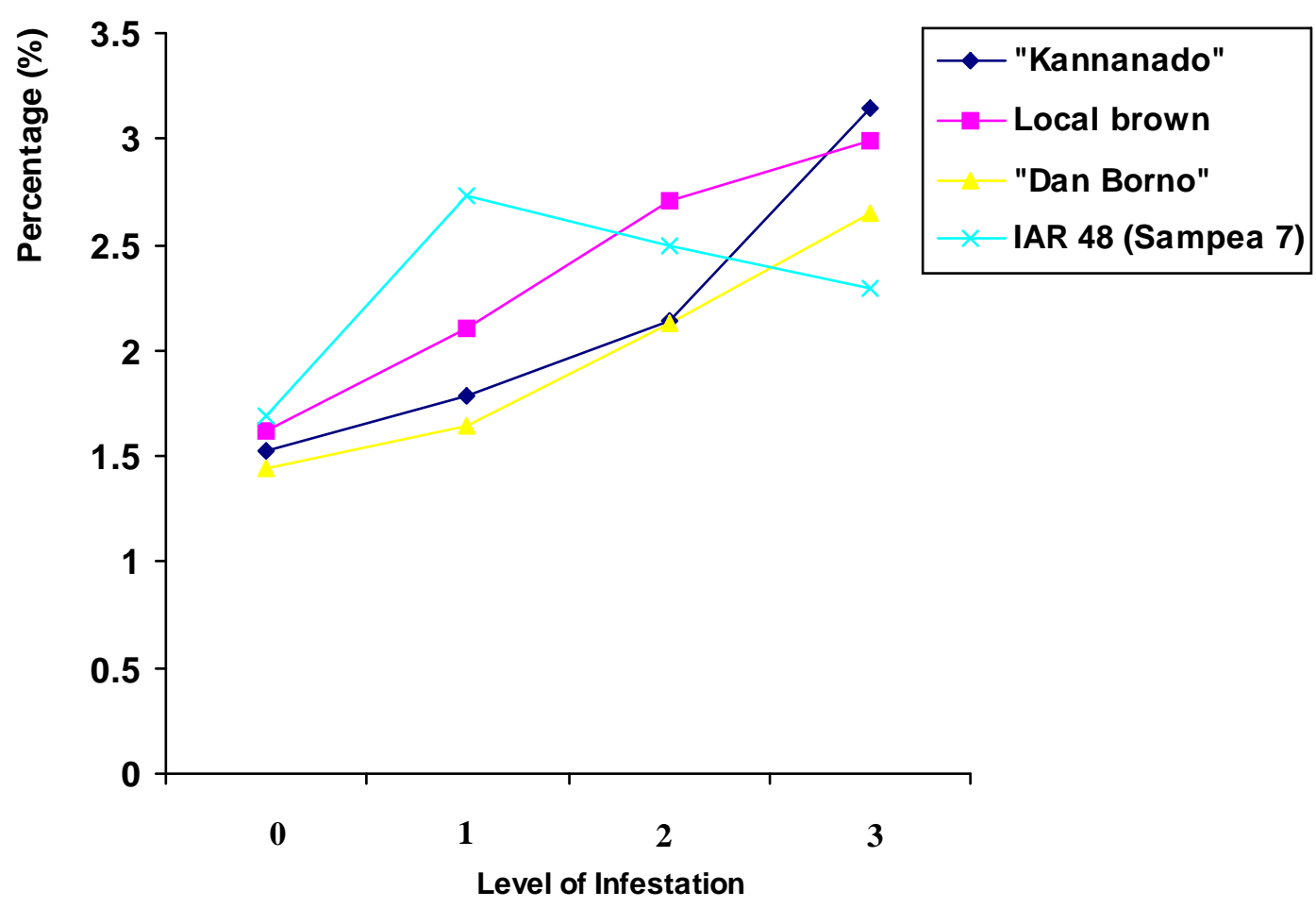

Fig. 2 Variation in moisture content (\%) with infestation

0-uninfested, 1-slightly Infested, 2-moderately Infested, 3-severely infested 


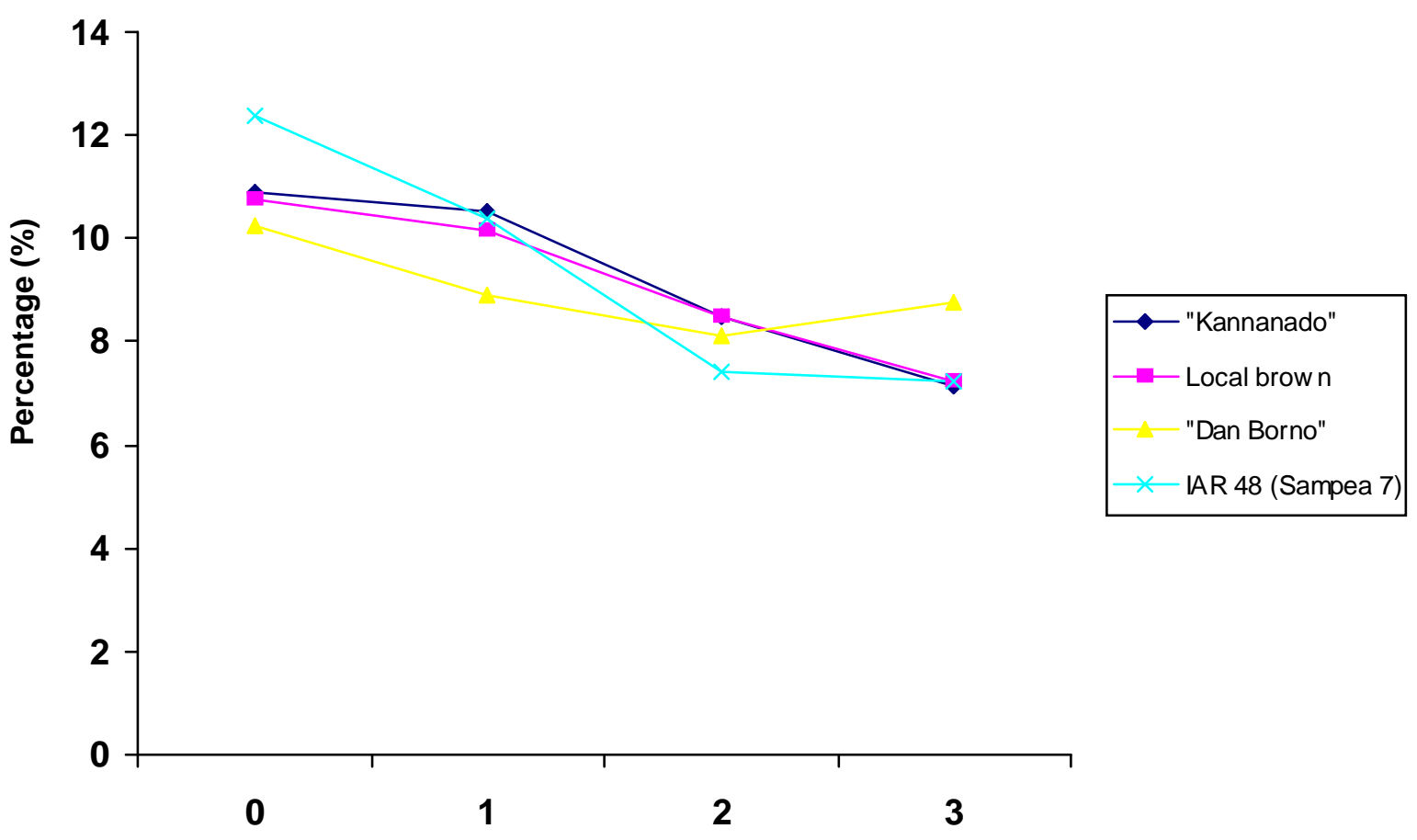

Fig. 3 Variation in moisture content (\%) with infestation

\author{
Levels of infestation
}

0-uninfested, 1 -slightly infested, 2 - moderately infested, 3 - severely infested 


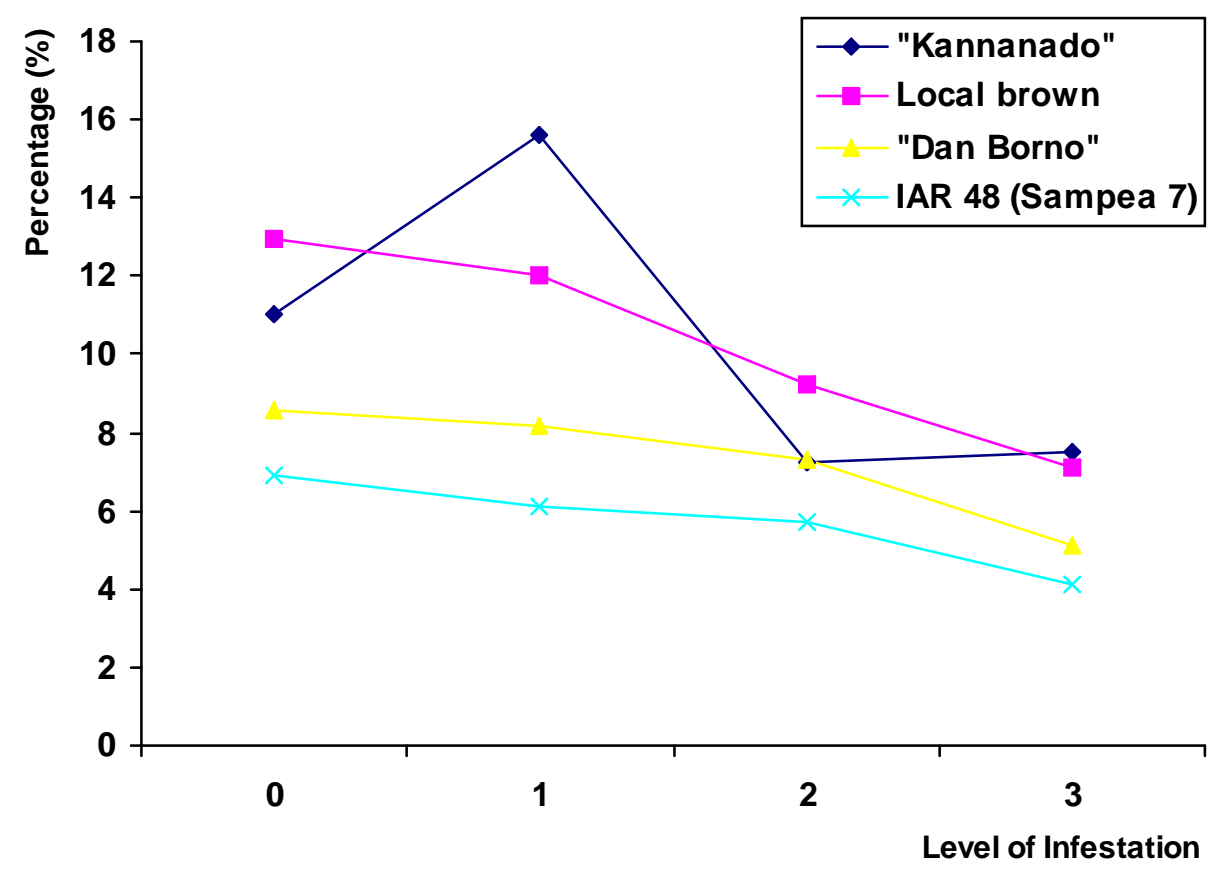

Fig. 4 Variation in moisture content $(\%)$ with infestation

0-uninfested, 1 -slightly Infested, 2-moderately infested, 3-severely infested 


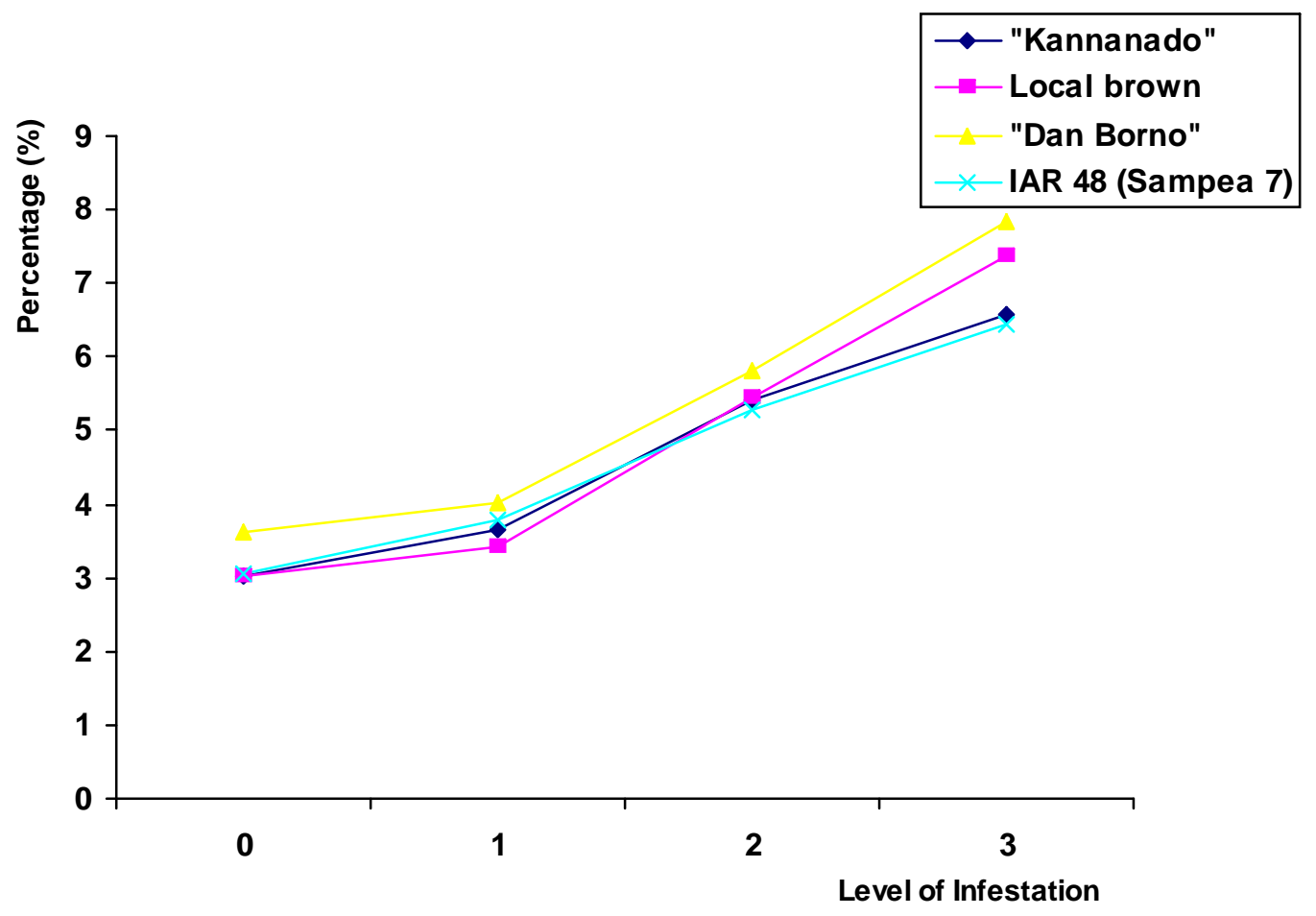

Fig. 5 Variation in moisture content (\%) with infestation

0-uninfested, 1 -slightly infested, 2 - moderately infested, 3 - severely infested 